\title{
Cloning, Expression and Toxicity of a Mosquitocidal Toxin Gene of Bacillus thuringiensis subsp. medellin
}

\author{
Nora Restrepo, Diana Gutierrez, Maria M Patiño, Isabelle Thiéry*, \\ Armelle Delécluse*, Sergio Orduz ${ }^{+}$
}

Unidad de Biotecnología y Control Biológico, Corporación para Investigaciones Biológicas, Apartado Aéreo 7378 , Medellín, Colombia *Unit de Bactéries Entomopathogènes, Institut Pasteur, 28 Rue du Dr Roux, 75724, Paris Cedex 15, France

Bacillus thuringiensis (Bt) subsp. medellin (Btmed) produces parasporal crystalline inclusions which are toxic to mosquito larvae. It has been shown that the inclusions of this bacterium contain mainly proteins of 94, 68 and 28-30 kDa. EcoRI partially digested total DNA of Btmed was cloned by using the Lambda Zap II cloning kit. Recombinant plaques were screened with a mouse policlonal antibody raised against the $94 \mathrm{kDa}$ crystal protein of Btmed. One of the positive plaques was selected, and by in vivo excision, a recombinant pBluescript $S K(-)$ was obtained. The gene encoding the $94 \mathrm{kDa}$ toxin of Btmed DNA was cloned in a $4.4 \mathrm{~kb}$ DNA fragment. Btmed DNA was then subcloned as a EcoRI/EcoRI fragment into the shuttle vector $p B U 4$ producing the recombinant plasmid $p B T M 3$ and used to transform by electroporation Bt subsp. israelensis (Bti) crystal negative strain 4Q2-81. Toxicity to mosquito larvae was estimated by using first instar laboratory reared Aedes aegypti, and Culex quinquefasciatus larvae challenged with whole crystals. Toxicity results indicate that the purified inclusions from the recombinant Bti strain were toxic to all mosquito species tested, although the toxicity was not as high as the one produced by the crystal of the Btmed wild type strain. Poliacrylamide gel electrophoresis indicate that the inclusions produced by the recombinant strain Bti (pBTM3) were mainly composed of the $94 \mathrm{kDa}$ protein of Btmed, as it was determined by Western blot.

Key words: Bacillus thuringiensis - crystal protein - gene cloning and expression - recombinant mosquito larval toxicity

During last years mosquito control programs worldwide have been evaluating the feasibility to implement microbiological control strategies by using Bacillus thuringiensis (Bt) subsp. israelensis (Bti) or B. sphaericus (Bs). Bt is an entomopathogenic Gram-positive bacterium that produces parasporal crystalline inclusions which are toxic to susceptible insect larvae when ingested, and one of the leading candidates to replace the wide spectrum environmentally unsafe chemical insecticides (Porter et al. 1993). The most toxic strains of $\mathrm{Bt}$ for mosquito control are those reported by Goldberg and Margalit (1977), Padua et al. (1984), Orduz et al. (1992, 1994), Seleena et al. (1995), and Ragni et al. (1996).

\footnotetext{
This research received financial support from Colciencias, the World Health Organization, the Institut Pasteur, and Corporación para Investigaciones Biológicas (CIB).

${ }^{+}$Corresponding author. Fax: +57-4-441.5514, e-mail: cibucb@medellin.cetcol.net.co

Received 30 June 1996

Accepted 27 November 1996
}

Bti parasporal crystalline inclusions contain four major polypeptides with molecular masses of $135,125,68$ and $28 \mathrm{kDa}$, which are referred as CryIVB, CryIVA, CryIVD, and CytA, respectively, according to the classification designed by Höfte and Whiteley (1989), and belonging to groups Cry4A, Cry4B, Cry11A, and CyT1A of the new proposed classification (D Dean, personal communication). Sodium dodecyl sulfate-polyacrylamide gel electrophoresis (SDS-PAGE) analysis of the parasporal crystalline inclusions purified from Btmed strain CIB 163-131 show polypeptides at approximately $94 \mathrm{kDa}$, multiple bands at 80,75 , $70,67,65 \mathrm{kDa}$, and two doublets at 40-41 and 28$30 \mathrm{kDa}$, and the matrix of the parasporal crystalline inclusions of Btmed determined by electron microscopy is somehow similar to that observed in Bti (Orduz et al. 1994).

The genes encoding the four crystal polypeptides of Bti have been cloned and the analysis of the cloned gene products has brought light over early controversial results on the interaction of the different crystal proteins and their resulting mosquito larval toxicity (Angsuthanasombat et al. 1992, Delécluse et al. 1993, Poncet et al. 1993, 
1995, Wu et al. 1994). Recently, the gene encoding the $80 \mathrm{kDa}$ toxic protein from Bt subsp. jegathesan (Btj) has been cloned, and sequenced. The gene product was found to posses a $58 \%$ homology with the Cry11A and therefore named Cry $11 \mathrm{~B}$, and the toxicity of the recombinant product was higher for Aedes aegypti larvae than the wild type strain (Delécluse et al. 1995). The role in toxicity of the $94 \mathrm{kDa}$ protein of Btmed is not clear, although Orduz et al. (1996), after purification of the Btmed toxins by size exclusion chromatography have suggested that the $94 \mathrm{kDa}$ protein is probably the most important component of the parasporal crystalline inclusions in the toxicity to Culex quinquefasciatus larvae.

In this article we report first, the cloning of a DNA fragment encoding the $94 \mathrm{kDa}$ crystal protein of Btmed in a crystal-negative strain of Bti and its expression, and second, the toxicity of purified inclusions produced by the recombinant $\mathrm{Bti}$ strain compared to the toxicity produced by purified crystals of the wild type strains CIB 163-131 of Btmed and 1884 of Bti against first instar larvae of $A$. aegypti and $C$. quinquefasciatus.

\section{MATERIALS AND METHODS}

Bacterial strains - Bti 4Q2-81, a crystal negative strain cured of all resident plasmid was used as recipient for the transformation experiments, and was kindly provided by D Dean (The Ohio State University, USA). Bti strain 1884 isolated from Israel is kept at the International Entomopathogenic Bacillus Centre of the Institut Pasteur Culture Collection. Btmed strain CIB 163-131 was isolated from Colombia (Orduz et al. 1992). These spore former bacteria are maintained at the Corporación para Investigaciones Biológicas Bacteria Culture Collection as spores in sterile filter paper packed into sterile sealed vials. Escherichia coli strains XL1-Blue MRF', and SOLR used for the genetic manipulations were obtained from Stratagene (La Jolla, CA, USA).

Gene cloning - A genomic library of Btmed strain CIB 163-131 was generated using the Lambda Zap II/EcoRI/CIAP cloning kit (Stratagene, La Jolla, CA, USA). Total DNA from Btmed was isolated, partially digested with EcoRI, and ligated to the vector as recommended by the manufacturer. Recombinant Lambda Zap DNA was packed in vitro and used to infect an E. coli XL1BLUE host. Library was plated and plaques were transferred to nitrocellulose membranes to be probed with a mouse antiserum raised against the $94 \mathrm{kDa}$ crystal protein of Btmed (Orduz et al. 1996). After purification of the positive plaques, one of them was selected for further characterization. Recombinant pBluescript SK(-) were ob- tained from the Lambda Zap II vector by in vivo excision and was used for the transduction of $E$. coli SOLR. Plasmid DNA was isolated from recombinant E. coli SOLR and the partial restriction map of the Btmed DNA fragment was determined by using restriction enzymes purchased from New England Biolabs (Beverly, MA, USA). The EcoRI/EcoRI Btmed DNA fragment from this clone was subcloned into the shuttle vector pBU4 (Bourgouin et al. 1990) to yield the recombinant plasmid pBTM3 that was used to transform by electroporation the crystal negative strain 4Q281 as described by Bone and Ellar (1989). This cloning vector contain a tetracycline resistance gene, and the concentration used for selection of recombinant bacteria was $30 \mu \mathrm{g} / \mathrm{ml}$.

Purification and solubilization of crystals Cultures of Btmed CIB 163-131, Bti, and the recombinant Bti strain 4Q2-81 (pBTM3) were grown in tests tubes containing $5 \mathrm{ml}$ of M-one liquid medium (per liter, Proflo $1 \mathrm{~g}$, peptone $5 \mathrm{~g}$, glucose $3 \mathrm{~g}, \mathrm{KH}_{2} \mathrm{PO}_{4} 6 \mathrm{~g}$, chloride salt solution $10 \mathrm{ml}$ containing $0.02 \mathrm{~g}$ of each one of the following $\mathrm{MgCl}_{2} \cdot 6 \mathrm{H}_{2} \mathrm{O}, \mathrm{MnCl}_{2} \cdot 4 \mathrm{H}_{2} \mathrm{O}, \mathrm{FeCl}_{3} \cdot 6 \mathrm{H}_{2} \mathrm{O}$, $\mathrm{ZnCl}_{2}$, and $\mathrm{CaCl}_{2} .2 \mathrm{H}_{2} \mathrm{O}$, phosphate buffer $200 \mathrm{ml}$, and $\mathrm{pH}$ adjusted to 7.2) supplemented with tetracycline $(30 \mu \mathrm{g} / \mathrm{ml})$ for $4 \mathrm{Q} 2-81$ (pBTM3). Cultures were incubated for $8 \mathrm{hr}$ at $30^{\circ} \mathrm{C}$ and $200 \mathrm{rpm}$. Bacterial cultures were transferred to flasks containing $50 \mathrm{ml}$ of M-one medium and grown during $12 \mathrm{hr}$. Finally, cultures were transferred to flasks containing 1 liter of $\mathrm{M}$-one liquid medium and incubated for $48 \mathrm{hr}$ at $30^{\circ} \mathrm{C}$ and $200 \mathrm{rpm}$ until sporulation. Once culture purity was confirmed by microscope observation, spore, crystal, and lysed cells were collected by centrifugation at 9,000 $\mathrm{rpm}$, at $4^{\circ} \mathrm{C}$ for $15 \mathrm{~min}$, resuspended in $1 / 20$ th of the original volume in $1 \mathrm{M} \mathrm{NaCl}$ and shaken for $30 \mathrm{~min}, 37^{\circ} \mathrm{C}$, and $150 \mathrm{rpm}$ to neutralize protease activity. Then washed twice with sterile destilled water, and the resulting pellets were resuspended in 1/20th of the original volume in destilled water, agitated with glass beads and dispersed by sonication three times for $15 \mathrm{sec}$ with a Branson sonifier.

Parasporal crystalline inclusions from Btmed, $\mathrm{Bti}$, and the recombinant Bti strain 4Q2-81 (pBTM3) were purified by the method described by Pendleton and Morrison (1966). This method use $\mathrm{CCl}_{4}, 1 \%$ of $\mathrm{Na}_{2} \mathrm{SO}_{4}$, and sterile destilled water and separate the crystals in a separation funnel. Purified crystals were washed three times with sterile destilled water and concentrated by centrifugation for $10 \mathrm{~min}$, at $4^{\circ} \mathrm{C}$ at $10,000 \mathrm{rpm}$. Finally, the crystals were resuspended in $5 \mathrm{ml}$ of sterile water, aliquoted, lyophilized and stored at $4^{\circ} \mathrm{C}$ until used. 
Fifteen milligrams of crystals from each strain were resuspended in $1 \mu \mathrm{l}$ of sterile destilled water. Five hundred $\mu l$ of this suspension were mixed with $2 \mathrm{ml}$ of a buffer, $\mathrm{pH} 11.3$ and gently shaken during $24 \mathrm{hr}$ at $30^{\circ} \mathrm{C}$ and $250 \mathrm{rpm}$, as described by Koller et al. (1992). The solubilized proteins were dialyzed against phosphate-buffer saline (PBS), $\mathrm{pH}$ 7.2 (containing per liter: $\mathrm{Na}_{2} \mathrm{HPO}_{4} 1.44 \mathrm{~g}, \mathrm{NaCl} 8$ $\mathrm{g}, \mathrm{KCl} 0.2 \mathrm{gr}, \mathrm{KH}_{2} \mathrm{PO}_{4} 0.24 \mathrm{~g}$ ). After solubilization, crystal protein concentration was measured by the BioRad technique (Hercules, CA, USA) using the microassay protocol. A standard curve was constructed using bovine gamma globulin.

Electrophoresis and Western blot - To determine the expression of the $94 \mathrm{kDa}$ protein of Btmed in the recombinant Bti strain 4Q2-81 (pBTM3), proteins were separated by sodium dodecyl sulfate-polyacrylamide gel electrophoresis (SDS-PAGE 10\%, acrylamide-bis- $N-N$, acrylamide). After separation, proteins were electro-transferred to nitrocellulose membranes and incubated for immunological detection with the mouse anti $94 \mathrm{kDa}$ Btmed crystal protein antiserum (Orduz et al. 1996), followed by incubation with protein A conjugated to alkaline phosphatase. After this incubation, a substrate/color system composed of naphtol phosphate/fast red was added (Sigma Chemical Co.).

Mosquitoes and toxic assays - A. aegypti, and C. quinquefasciatus larvae used in these experiments were collected in the vicinity of Medellin. The mosquito species are maintained under laboratory conditions at $30 \pm 2^{\circ} \mathrm{C}$ under a 12:12 (light: dark) photoperiod. Bioassays were conducted using lyophilized parasporal inclusion preparations of each Bt strain. Fifteen milligrams of lyophilized parasporal inclusions were suspended in $1 \mathrm{ml}$ of sterile destilled water and serially diluted in $0.9 \mathrm{ml}$ of sterile destilled water. Different quantities of these dilutions were tested against $A$. aegypti, and C. quinquefasciatus larvae. Five, first instar larvae were placed in each one of a 24 well plate with $1 \mathrm{ml}$ of deionized water, and parasporal inclusion suspensions were given; finally, $5 \mathrm{mg}$ of trout feed were added. Three replicates, consisting of three wells per dilution were included, and assayed in three different days. Twenty-four hours later, larval mortality was scored. Half lethal concentration $\left(\mathrm{LC}_{50}\right)$ was calculated by Probit analysis with the help of a computer program for Macintosh designed by E Franhon (Institut Pasteur, Paris).

\section{RESULTS}

Characterization and analysis of clone 3A6$1 A$ - Screening of the Btmed genomic library permitted to obtain recombinant plaques expressing the $94 \mathrm{kDa}$ protein of Btmed strain CIB 163-131 as it was recognized by the corresponding mouse antiserum. From one of the positive and selected plaques (3A6-1A), the recombinant plasmid pBluescript was obtained by in vivo excision. This plasmid contains an EcoRI insert of $4.4 \mathrm{~kb}$ containing the $94 \mathrm{kDa}$ protein gene. Partial restriction map of the $4.4 \mathrm{~kb}$ DNA fragment from Btmed is shown in Fig. 1. This fragment was then subcloned into the shuttle vector pBU4, which is able to replicate in $\mathrm{Bt}$, and later introduced by electroporation into the crystal negative strain 4Q2-81, yielding strain 4Q2-81 (pBTM3).

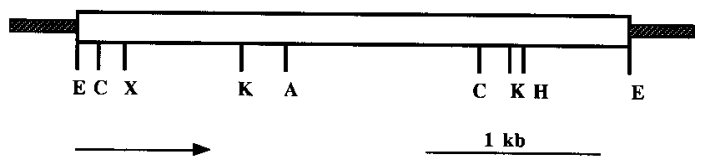

Fig. 1: partial restriction map of the recombinant plasmid pBTM3 containing the DNA fragment encoding the $94 \mathrm{kDa}$ toxin gene of Bacillus thuringiensis subsp. medellin. Hatched bar vector pBluescript. Abbreviations: A, AciI; C, ClaI; E, EcoRI; H, HindIII; K, KpnI; X, XbaI. Arrow indicate direction of transcription.

Expression of the $94 \mathrm{kDa}$ protein of Btmed in the crystal negative strain 4Q2-81 - Microscopic observations of a $48 \mathrm{hr}$ culture of the recombinant cells containing the DNA fragment encoding the $94 \mathrm{kDa}$ crystal protein of Btmed revealed the presence of large parasporal inclusions, which in general, were bigger than those produced by the wild type strains CIB 163-131 of Btmed and 1884 of Bti. Purified and lyophilized inclusions of the Bt strains were subjected to SDSPAGE and the gel was stained with Coomassie brillant blue (Fig. 2A). Native strain CIB 163-131 of Btmed produced four major crystal polypeptides of 94, 68 and 28-30 kDa (Fig. 2A, lane 1). Enriched preparations of parasporal crystalline inclusions of recombinant strain 4Q2-81 (pBTM3) contained a major polypeptide of 94 $\mathrm{kDa}$ which has the same electrophoretic mobility as the largest polypeptide in the crystal of the wild type strain CIB 163-131 (Fig. 2A, lane 2). In Western blot the recombinant protein synthesized by the Bti strain 4Q2-81 (pBTM3) co-migrated with the $94 \mathrm{kDa}$ crystal protein of Btmed in SDS-PAGE and it is the only polypeptide recognized by the mouse anti-94 kDa antibody (Fig. 2B, lane 2), and no protein was recognized by the mouse antiserum in the parasporal crystalline inclusions of Bti (Fig. 2B, lane 3). 


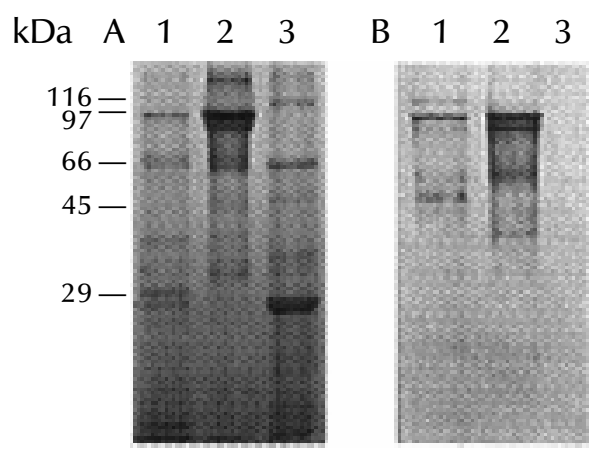

Fig. 2: protein analysis of inclusions from wild-type Bacillus thuringiensis subsp. medellin (Btmed), B. thuringiensis subsp. israelensis (Bti) and recombinant strain 4Q2-81 (pBTM3). (A) $10 \mu \mathrm{g}$ of purified inclusions were subjected to electrophoresis on a $10 \%$ SDS-polyacrylamide gel. Lane 1, Wild-type Btmed strain CIB 163-131; lane 2, Bti recombinant strain 4Q2-81 (pBTM3); lane 3, Bti strain 1884. (B) Purified inclusions were subjected to electrophoresis as above and transferred to a nitrocellulose membrane. The membrane was probed with antibody raised against the Btmed 94 toxic protein. For immunodetection, alkaline-phosphatase conjugated to Protein A was used. Lane 1, Wild-type Btmed strain CIB 163-131; lane 2, Bti recombinant strain 4Q2-81 (pBTM3); lane 3, Bti strain 1884.

Toxicity of the $94 \mathrm{kDa}$ crystal protein - DNA fragment encoding the $94 \mathrm{kDa}$ crystal protein of Btmed cloned and expressed in E. coli SOLR, produced significant mortality when whole cells were given to third instar $C$. quinquefasciatus larvae, with and without $24 \mathrm{hr}$ induction with isopropylthio- $\beta-D-$ galactoside (data not shown). Purified and lyophilized inclusions from Btmed strain CIB 163-131, Bti strain 1884, Bti strain 4Q2-81 (pBTM3) and final whole culture of Bti strain 4 Q2-81 were assayed for mosquitocidal activity with first instar $A$. aegypti, and $C$. quinquefasciatus larvae. The inclusions produced by the recombinant Bti strain 4Q2-81 (pBTM3) that expresses the $94 \mathrm{kDa}$ polypeptide of Btmed, and the wild type strains CIB 163-131 of Btmed and 1884 of Bti were toxic to the mosquito species tested (Table). Although a differential susceptibility by mosquito species to the same 94 $\mathrm{kDa}$ toxic protein of Btmed was observed in all mosquito species, the recombinant inclusions were not as active as the crystals produced by the wild type strains of Btmed and Bti, and had an $\mathrm{LC}_{50}$ of $43 \mathrm{ng} / \mathrm{ml}$, which is approximately 4-times lower than the toxicity produced by the wild type strain of Btmed in C. quinquefasciatus larvae, and 69.6 $\mathrm{ng} / \mathrm{ml}$, which is 9-times lower for A. aegypti larvae. Toxicity of the wild type Bti strain 1884 was 17-times higher than the recombinant strain Bti 4Q2-81 (pBTM3) in A. aegypti larvae, and approximately 9-times higher in $C$. quinquefasciatus larvae.

\section{DISCUSSION}

To elucidate the role of the $94 \mathrm{kDa}$ crystal polypeptide of Btmed in toxicity towards mosquito larvae, cloning experiments were conducted as well as bioassays with the purified inclusions produced by a recombinant Bti strain harboring the DNA fragment encoding this Btmed protein. Recombinant Bti strain 4Q2-81 (pBTM3) expressed the $94 \mathrm{kDa}$ toxic gene of Btmed at high levels, and the host cells were able to pack the protein as parasporal inclusions visible under light microscopy. The size of the parasporal inclusion produced by the recombinant strain Bti 4Q2-81 (pBTM3) were bigger than those produced by the wild type strains of Btmed and Bti, contrasting the results of Delécluse et al. (1993) who observed that the Bti 4Q2-81 recombinant strain harboring the $c r y 4 \mathrm{~B}$ gene produced smaller inclusions, while the Bti 4Q2-81 recombinant strain harboring the

TABLE

Toxic activity of purified crystals from Bacillus thuringiensis strains in different first instar larvae of two mosquito species

\begin{tabular}{|c|c|c|c|}
\hline \multirow[b]{2}{*}{ Strain } & \multirow[b]{2}{*}{ Crystal type } & \multicolumn{2}{|c|}{ Mosquitocidal activity $\mathrm{LC}_{50}(\mathrm{ng} / \mathrm{ml})^{a}$} \\
\hline & & Aedes aegypti & Culex quinquefasciatus \\
\hline Btmed & Wild type & $7.5(6.3-8.9)$ & $10.9(8.8-13.5)$ \\
\hline 4Q2-81 (pBTM3) & $94 \mathrm{kDa}$ protein ${ }^{b}$ & $69.6(54.6-88.7)$ & $43.0(33.4-54.9)$ \\
\hline Bti & Wild type & $4.1(3.5-4.7)$ & $4.9(4.1-6.0)$ \\
\hline 4Q2-81 & Negative & NT & NT \\
\hline
\end{tabular}

$a$ : values represent the average of three assays (see Materials and Methods). Numbers in parentheses are $95 \%$ confidence limits, determined by Probit analysis.

Btmed, Bacillus thuringiensis subsp. medellin; 4Q2-81, crystal negative strain of Bti harbouring the DNA fragment encoding the $94 \mathrm{kDa}$ toxin gene; Bti, Bacillus thuringiensis subsp. israelensis; 4Q2-81, crystal negative strain of Bti; NT, not toxic. 
cry $4 \mathrm{~A}$ gene did not produce parasporal inclusions when cloned in a low copy number plasmid, but they were seen when cloned in a higher copy number plasmid, in either case, sporulated cultures were toxic to mosquito larvae. The size and antigenic properties of the protein encoded by this DNA fragment is apparently not common to other $\mathrm{Bt}$ mosquito active strains isolated to date. When tested in bioassays, recombinant strain 4Q2-81 (pBTM3) was toxic to first instar A. aegypti and $C$. quinquefasciatus larvae, confirming the identity of the clone as an insecticidal crystal protein of Btmed. Preliminary results of the activity of individual proteins purified by size exclusion chromatography suggest that the $94 \mathrm{kDa}$ protein is perhaps the most important component of the Btmed toxins with the lowest $\mathrm{LC}_{50}$ of $82.6 \mathrm{ng}$ of protein/ $\mathrm{ml}$ against $C$. quinquefasciatus larvae (Orduz et al. 1996), contrary to the observation of Chilcott and Ellar (1988) on Bti, where they found that in this Bt subspecies the most toxic component of the crystal was the $68 \mathrm{kDa}$ protein. It has been suggested that proteins of 68 and $30 \mathrm{kDa}$ of Btmed have a minor role in toxicity towards $C$. quinquefasciatus larvae (Orduz et al. 1996).

Toxicity of the recombinant Cry4A protein of Bti is between 21- and 22-times lower than the recombinant $94 \mathrm{kDa}$ protein of Btmed in Aedes and Culex species as indicated by the toxicity data reported by Angsuthanasombat et al. (1992), although there were differences in the larval age in the two bioassays being compared. In the case of the recombinant Cry4B protein of $\mathrm{Bti}$, Angsuthanasombat et al. (1992) has reported $\mathrm{LC}_{50}$ values of 940 and $24,500 \mathrm{ng} / \mathrm{ml}$ for the mosquito species A. aegypti and C. quinquefasciatus respectively, which are 13.5 and 569 lower than the $\mathrm{LC}_{50}$ found for the $94 \mathrm{kDa}$ protein of Btmed in the same mosquito species. Toxicity data reported by Delécluse et al. (1993) and Poncet et al. (1995) in mosquitoes of the genera Aedes, Anopheles and Culex when used the Cry4 recombinant proteins are comparable to those reported by Angsuthanasombat et al. (1992) for the same Bti proteins, and therefore have lower toxicity than the recombinat Btmed protein of $94 \mathrm{kDa}$. Contrasting these results, similar toxicity found between the $94 \mathrm{kDa}$ protein from Btmed and the Cry11A as reported by $\mathrm{Wu}$ et al. (1994) on the same larval age of $A$. aegypti, suggests that the 94 $\mathrm{kDa}$ protein of Btmed could be more related to Cry11A than to Cry4A or Cry4B. Similar toxicity of the recombinant proteins Cry $11 \mathrm{~B}$ from Btj and the $94 \mathrm{kDa}$ protein from Btmed indicate that these two Bt proteins could also be close related. The homology between the Cry11A crystal protein of
Bti and the Cry11B crystal protein Btj has been reported as 58\% (Delécluse et al. 1995). The sequence similarities between Cry11A and Cry 11B, and the toxicity similarities between the Cry11A and the $94 \mathrm{kDa}$ crystal protein from Btmed could indicate that these three proteins are in some degree related.

Further experiments with other Btmed cry genes encoding the 68 and $30 \mathrm{kDa}$ polypeptides are needed to elucidate the synergism between the crystal components and the mode of action of Btmed toxic proteins. Sequencing in progress of the $4.4 \mathrm{~kb}$ DNA fragment encoding the $94 \mathrm{kDa}$ toxin protein of Btmed will confirm the evolutionary relationship with the other Bt crystal proteins.

\section{REFERENCES}

Angsuthanasombat C, Crickmore N, Ellar DJ 1992. Comparison of Bacillus thuringiensis subsp. israelensis CryIVA and CryIVB cloned toxins reveals synergism in vivo. FEMS Microbiol Lett 94: 63-68.

Bone EJ, Ellar DJ 1989. Transformation of Bacillus thuringiensis by electroporation. FEMS Microbiol Lett 58: 171-178.

Bourguoin C, Delécluse A, de la Torre F, Szulmajster J 1990. Transfer of the toxin protein genes of Bacillus sphaericus into Bacillus thuringiensis subsp. israelensis and their expression. Appl Environm Microbiol 56: 340-344.

Chilcott CN, Ellar D 1988. Comparative toxicity of Bacillus thuringiensis var. israelensis crystal proteins in vivo and in vitro. J Gen Microbiol 134: 2551-2558.

Delécluse A, Poncet S, Klier A, Rapoport G 1993. Expression of cryIVA and cryIVB genes, independently or in combination, in a crystal-negative strain of $\mathrm{Ba}$ cillus thuringiensis subsp. israelensis. Appl Environm Microbiol 59: 3922-3927.

Delécluse A, Rosso M-L, Ragni A 1995. Cloning and expression of a novel toxin gene from Bacillus thuringiensis subsp. jegathesan encoding a highly mosquitocidal protein. Appl Environm Microbiol 61: 4230-4235.

Goldberg LJ, Margalit J 1977. A bacterial spore demonstrating rapid larvicidal activity against Anopheles sergentii, Uranotaenia unguiculata, Culex univitattus, Aedes aegyti and Culex pipiens. Mosq News 37: 355-358.

Höfte H, Whiteley HR 1989. Insecticidal crystal proteins of Bacillus thuringiensis. Microbiol Rev 53: 242255.

Koller CN, Bauer LS, Hollingworth RM 1992. Characterization of the $\mathrm{pH}$-mediated solubility of Bacillus thuringiensis var. san diego native delta endotoxin crystals. Biochem Biophys Res Comm 184: 692-699.

Orduz S, Diaz T, Restrepo N, Patiño MM, Tamayo MC 1996. Biochemical, immunological and toxicological characteristics of the crystal proteins of Bacillus thuringiensis subsp. medellin. Mem Inst Oswaldo Cruz 91: 231-237. 
Orduz S, Diaz T, Thiéry I, Charles JF, Rojas W 1994. Crystal proteins from Bacillus thuringiensis serovar medellin. Appl Microbiol Biotechnol 40: 794-799.

Orduz S, Rojas W, Correa MM, Montoya AE, de Barjac H 1992. A new serotype of Bacillus thuringiensis from Colombia toxic to mosquito larvae. J Invertebr Pathol 59: 99-103.

Padua LE, Ohba M, Aizawa K 1984. Isolation of a Bacillus thuringiensis strain (serotype $8 \mathrm{a}, 8 \mathrm{~b}$ ) highly and selectively toxic against mosquito larvae. J Invertebr Pathol 44: 12-17.

Pendleton IR, Morrison RB 1966. Separation of the spores and crystals of Bacillus thuringiensis. Nature 212: 728-729.

Poncet S, Anello G, Delécluse A, Klier A, Rapoport G 1993. Role of the CryIVD polypeptide in the overall toxicity of Bacillus thuringiensis subsp. iraelensis. Appl Environm Micorbiol 59: 3928-3930.

Poncet S, Delécluse, A, Klier A, G Rapoport 1995. Evaluation of synergistic interaction among the CryIVA, CryIVB, and CryIVD toxic components of $B$. thuringiensis subsp. israelensis crystals. J Invertebr Pathol 66: 131-135.

Porter AG, Davidson EW, Liu JW 1993. Mosquitocidal toxins from Bacilli and their genetic manipulation for effective biological control of mosquitoes. Microbiol Rev 57: 838-861.

Ragni A, Thiery I, Delécluse A 1996. Characterization of six highly mosquitocidal Bacillus thuringiensis strains that do not belong to H-14 serotype. Curr Microbiol 32: 48-54.

Seleena P, Lee HL, Lecadet MM 1995. A new serovar of Bacillus thuringiensis possesing 28a:28c flagellar antigenic structure: Bacillus thuringiensis serovar jegathesan, selectively toxic to mosquito larvae. $J$ Amer Mosq Control Assoc 11: 471-473.

Wu D, Johnson JJ, Federici BA 1994. Synergism of mosquitocidal toxicity between CytA and CryIVD proteins using inclusions produced from cloned genes of Bacillus thuringiensis. Mol Microbiol 13: 965 972. 